\title{
EVALUASI KEPUASAN PELANGGAN TERHADAP KINERJA MANAJEMEN PROYEK KONTRAKTOR BESAR \\ (STUDI KASUS : PROYEK PEMBANGUNAN BENDUNGAN KLM DI PROVINSI BANTEN)
}

\author{
oleh : \\ Andi Madeppungeng \\ Teknik Sipil Universitas Sultan Ageng Tirtayasa \\ Email : andi_made@yahoo.com \\ Dwi Esti Intari \\ Teknik Sipil Universitas Sultan Ageng Tirtayasa \\ Email : dwiesti@untirta.ac.id \\ Nuzulan Nur Fauziah \\ Teknik Sipil Universitas Sultan Ageng Tirtayasa \\ Email : nuzulannurfauziah@yahoo.com
}

\begin{abstract}
Abstrak : Bendungan KLM merupakan mega proyek provinsi Banten. Bendungan KLM apabila dilihat dalam fungsinya maka bendungan ini berjenis bendungan serbaguna, yaitu pembangunan bendungan tidak hanya bertujuan untuk memperoleh manfaat tunggal, tapi untuk lebih dari satu manfaat seperti : untuk penyedia air irigasi, tenaga listrik, air baku, pengendali banjir, perikanan, rekreasi dan lain sebagainya. Penelitian ini menggunakan metode survei lapangan dengan melakukan pengamatan di lokasi proyek pembangunan Bendungan KLM untuk mengevaluasi kepuasan pelanggan terhadap kinerja manajemen proyek kontraktor besar di bendungan KLM dan penyebaran kuesioner yang digunakan untuk mengukur kinerja manajemen proyek dari sudut pandang tingkat kepuasan dan kepentingan. Selanjutnya dilakukan evaluasi dengan tiga metode yaitu metode customer satisfaction index (CSI), metode analisis gap, dan metode importance performance analysis (IPA). Identifikasi tingkat kepuasan pelanggan terhadap pelaksanaan manajemen proyek sebesar $68,64 \%$, berdasarkan analisa CSI termasuk kategori puas. Hasil analisis kesenjangan, nilai total skor gap tertinggi terdapat pada variabel ketepatan waktu penyelesaian proyek (S2) sebesar 84 yang berarti pelanggan merasa sangat tidak puas terhadap kinerja variabel tersebut, dan total skor gap terendah terdapat pada variabel mengutamakan kepentingan pemilik (S30) sebesar 29 yang berarti pelanggan merasa sangat puas terhadap kinerja variabel tersebut. Sementara itu, berdasarkan metode IPA, kesesuaian laporan proyek dengan kondisi aktual di lapangan (S6) menjadi indikator prioritas yang perlu ditingkatkan demi mencapai kepuasan pengguna jasa yang lebih baik lagi.
\end{abstract}

Kata Kunci : Kepuasan pelanggan, Manajemen proyek, Customer Satisfaction Index (CSI), Importance Performance Analysis (IPA).

Abstract : KLM Dam is a Banten provincial mega project. From its function, this dam is a multipurpose dam type, with more than one benefit such as: for providers of irrigation water, electricity, raw water, flood control, fisheries, recreation and others so. This study uses a field survey method by observing the location of the KLM Dam development project to evaluate customer satisfaction with the performance of the large contractor project management at the KLM dam and distributing questionnaires used to measure project management performance from the point of view of satisfaction and importance. Further evaluation by three methods: methods of customer satisfaction index (CSI), gap analysis method, and the method of importance 
performance analysis (IPA). The customer satisfaction level with the implementation of project management is $68,64 \%$, based on CSI analysis including satisfied category. The result of gap analysis, the highest total gap score is 84 which means that customers is very dissatisfied with the performance of the project completion time (S2), and the lowest total gap is 29 which means that customers is very satisfied with the performance of the prioritizing owner's needs (S30). Meanwhile, based on IPA method, suitability of project reports with actual conditions (S6) became a priority indicator that needs to be improved in order to achieve the satisfaction of serice user better yet.

Keywords : Customer Satisfaction, Project Management, Customer Satisfaction index (CSI), Importance performance analysis (IPA).

\section{Pendahuluan}

Peningkatan kualitas kinerja dan produk dalam industri konstruksi dapat dilakukan dengan menerapkan sistem manajemen proyek. Manajemen proyek adalah aplikasi pengetahuan (knowledges), keterampilan (skills), alat (tools) dan teknis (techniques) dalam aktivitas-aktivitas proyek untuk memenuhi kebutuhan-kebutuhan proyek. Manajemen proyek sangat diperlukan bagi pelaksanaan suatu pekerjaan menjadi lebih efisien dan efektif. Penerapan manajemen proyek konstruksi akan memerlukan pengetahuan tentang berbagai aspek seperti integrasi, lingkup, mutu, biaya, waktu, resiko, komunikasi, sumber daya manusia, pengadaan, (Project Management Body of Knowledges,2008). Dengan penerapan sitem manajemen proyek tersebut diharapkan badan usaha jasa konstruksi dapat meningkatkan kualitas pelayanan dan produknya sehingga dapat memenuhi sasaran dan tujuan proyek guna mencapai harapan dan kepuasan pelanggan, di mana pelanggan konstruksi merupakan seseorang/ badan/ organisasi yang membayar penyedia jasa konstruksi.

\section{Pelayanan dan Kepuasan Pelanggan}

Pelayanan adalah usaha melayani kebutuhan orang lain. Untuk instansi yang mempunyai standar pelayanan, maka pelayanan adalah melebihi standar yang ada atau sesuai dengan standar yang ada, sedangkan bagi instansi yang belum mempunyai standar pelayanan, maka pelayanan berarti pelayanan yang terbaik yang dapat diberikan, pelayanan yang mendekati apa yang dianggap pelayanan standard dan pelayanan yang dilakukan secara maksimal.

Kepuasan pelanggan merupakan evaluasi purna beli di mana alternatif yang dipilih sekurang- kurangnya memberikan hasil yang sama atau melampui harapan pelanggan. Jadi sebenarnya ada 2 (dua) faktor yang sangat menentukan kepuasan yaitu harapan pelanggan dan kinerja atau hasil yang mereka rasakan (Tjiptono,2001).

\section{Manajemen Proyek Konstruksi}

Manajemen adalah proses merencanakan, mengorganisir, memimpin dan mengendalikan kegiatan anggota serta sumber daya yang lain untuk mencapai sasaran organisasi yang telah ditentukan. Sedangkan manajemen proyek adalah manajemen yang diterapkan pada suatu proyek untuk mencapai suatu hasil tertentu, atau, manajemen proyek adalah suatu ilmu dan seni untuk mengadakan perencanaan (planning), pengorganisasian (organizing), pengarahan (directing), pengoordinasian (coordinating), dan mengadakan pengawasan (controlling) terhadap orang 
dan barang untuk mencapai tujuan tertentu dari suatu proyek (Iman Soeharto, 1995).

Dalam melakukan manajemen pada sebuah proyek, maka kita harus memahami 5 tahap proses manajemen proyek, yaitu:

1) Tahap Inisiasi, dalam tahap ini permasalahan yang ingin diselesaikan akan didefinisikan.

2) Tahap perencanaan dan desain, yaitu mendefinisikan tujuan dan merencanakan kegiatan-kegiatan yang diperlukan untuk mencapai tujuan dan lingkup proyek.

3) Tahap pelaksanaan, yaitu untuk mengintegrasikan orang-orang dan sumber daya lainnya untuk menjalankan rencana manajemen proyek.

4) Tahap pengawasan dan pengendalian, dalam tahap ini bertujuan untuk mengukur dan memonitor progress untuk mengidentifikasi penyimpangan dari rencana manajemen proyek sehingga tindakan koreksi dapat dilakukan bila diperlukan dalam mencapai tujuan proyek.

5) Tahap penutupan, dalam tahap ini hasil akhir proyek beserta dokumentasinya diserahkan kepada pemilik.

\section{Customer Satisfaction Index (CSI)}

Customer Satisfaction Index (CSI) digunakan untuk mengetahui tingkat kepuasan pengguna jasa secara menyeluruh dengan melihat tingkat kinerja dan tingkat kepentingan/harapan dari atribut-atribut jasa pelayanan.

Metode pengukuran CSI meliputi tahaptahap sebagai berikut (Stratford, 2008) :

1. Menghitung nilai mean important score (MIS) untuk seluruh variabel evaluasi kinerja manajemen proyek dan menjumlahkan (Total MIS)
2. Menghitung weight importance factor (WF) dari nilai mean tingkat kepentingan (MIS) menjadi angka presentase dari total nilai mean tingkat kepentingan (Total MIS), sehingga didapatkan total weight importance factor (WF) $100 \%$

$$
\mathrm{WF}=\frac{\text { MIS }}{\text { Total MIS }} \times 100 \%
$$

3. Menghitung weighted score (WS), yaitu bobot perkalian antara WF dengan mean satisfaction score (MSS) untuk masing-masing variabel

$$
\mathrm{WS}=\mathrm{WF} \times \mathrm{MSS}
$$

4. Menghitung weighted average total (WAT), yaitu menjumlahkan weighted score (WS) dari semua variabel $\mathrm{WAT}=\mathrm{WS} 1+\mathrm{WS} 22+\ldots \ldots .+\mathrm{WS} 36$

5. Menghitung customer satisfaction index (CSI), yaitu weighted average total (WAT)dibagi high scale (HS), skala maksimal yang digunakan (skala penilaian 6)

$$
\mathrm{CSI}=\frac{\mathrm{WAT}}{\mathrm{HS}} \times 100 \%
$$

Berdasarkan Simamora (2005), untuk membuat skala numerik rentang skala (RS) dapat dihitung dengan:

$$
\mathrm{RS}=\frac{\mathrm{m}-\mathrm{n}}{\mathrm{b}}
$$

Dimana: $\mathrm{m}=$ skor tertinggi

$$
\begin{array}{ll}
\mathrm{n} & =\text { skor terendah } \\
\mathrm{b} & =\text { jumlah kelas atau kategori }
\end{array}
$$

Dalam penelitian ini, nilai RS $=(100-0) / 6 \mathrm{x}$ $100 \%=16.67 \%$. Hasil perhitungan rentang skala maka kriteria kepuasannya adalah sebagai berikut:

$$
\begin{array}{ll}
0 \%<\mathrm{CSI} \leq 16.67 \% & =\text { Sangat tidak } \\
& \text { puas } \\
16.67 \%<\mathrm{CSI} \leq 33.34 \% & =\text { Tidak puas } \\
33.34 \%<\mathrm{CSI} \leq 50 \% & =\text { Kurang Puas } \\
50 \%<\mathrm{CSI} \leq 66.66 \% & =\text { Cukup puas } \\
66.66 \%<\mathrm{CSI} \leq 83.33 \% & =\text { Puas } \\
83.35 \%<\mathrm{CSI} \leq 100 \% & =\text { Sangat Puas }
\end{array}
$$




\section{Analisis GAP}

Evaluasi kepuasan pelanggan ini dilakukan pula dengan analisa gap, pada analisis gap, perhitungan evaluasi kepuasan pelanggan dilakukan dengan menghitung selisih (gap) antara penilaian skor tingkat kepuasan dengan penilaian skor tingkat kepentingan untuk seluruh variabel-variabel evaluasi kinerja manajemen proyek. Sebelum melakukan perhitungan analisis kesenjangan (gap) dimulai dengan membuat selang frekuensi yang berguna untuk mengetahui suatu penilaian dari variabel kinerja manajemen proyek. di mana perhitungan nilai selang frekuensi ini dipengaruhi oleh banyaknya jumlah responden, yang akan berpengaruh terhadap hasil perhitungan nilai skor gap tertinggi dan nilai skor gap terendah (Walpole, 1993 dalam Vica Julia,2015).

\section{Selang Frekuensi $=$ $\underline{\text { nilai skor gap tertinggi-nilai skor gap terendah }}$ jumlah kelas}

Berdasarkan hasil perhitungan selang frekuensi, maka kriteria kepuasan untuk analisa kesenjangan (gap) adalah sebagai berikut :

$\begin{array}{ll}84-74.9 & =\text { Sangat Tidak Puas } \\ 74.9-65.7 & =\text { Tidak Puas } \\ 65.7-56.5 & =\text { Kurang Puas } \\ 56.5-47.3 & =\text { Cukup Puas } \\ 47.3-38.2 & =\text { Puas } \\ 38.2-29 & =\text { Sangat Puas }\end{array}$

\section{Important Performance Analysis (IPA)}

Metode Importance Performance Analysis (IPA) pertama diperkenalkan oleh Martilla dan James (1977) untuk mengukur hubungan antara persepsi konsumen dan prioritas peningkatan kualitas produk/jasa yang dikenal dengan analisis kuadran. Metode Importance Performance Analysis (IPA) mempunyai fungsi utama untuk menampilkan informasi berkaitan dengan faktor-faktor pelayanan yang menurut konsumen perlu ditingkatkan karena saat ini belum memuaskan. Tahapannya adalah sebagai berikut :

1. Berdasarkan hasil penilaian tingkat kepentingan dan hasil penilaian kinerja lalu ditentukan tingkat kesesuaian antara tingkat kepentingan dan tingkat kinerja klien.

$$
T k i=\frac{X i}{Y i} \times 100 \%
$$

Keterangan:

Tki = Tingkat kesesuaian responden

$\mathrm{Xi}=$ Skor penilaian tingkat kinerja

$\mathrm{Yi}=$ Skor penilaian tingkat kepentingan

2. Pada sumbu mendatar (X) akan diisi oleh skor tingkat pelaksanaan sedangkan sumbu tegaknya akan diisi oleh skor tingkat kepentingan.:

$$
\begin{aligned}
& \bar{X} \frac{\Sigma X i}{n} \\
& \bar{Y} \frac{\Sigma X i}{n}
\end{aligned}
$$

Keterangan:

$\bar{X} \quad=$ Skor rata-rata tingkat kinerja klien

$\bar{Y} \quad=$ Skor rata-rata tingkat kepentingan terhadap kepuasan kontraktor

$\mathrm{n} \quad=$ Jumlah responden

3. Menghitung rata-rata seluruh atribut tingkat kepentingan $(\bar{Y})$ dan kinerja $(\bar{X})$ yang menjadi batas pada diagram kartesius, dengan rumus:

Keterangan:

$$
\begin{gathered}
\bar{X} \frac{\sum X i}{k} \\
\bar{Y} \frac{\sum X i}{k}
\end{gathered}
$$

$\bar{X}=$ Rata-rata skor tingkat pelaksanaan atau kinerja klien seluruh faktor atau atribut

$\bar{Y} \quad$ = Rata-rata tingkat kepentingan seluruh atribut yang mempengaruhi kepuasan kontraktor 
$\mathrm{k}=$ Banyaknya atribut yang dapat mempengaruhi kualitas produk

4. Melakukan pemetaan ke dalam diagram kartesius.

$$
\begin{aligned}
& \overline{\bar{X}}=\frac{\sum_{i=1}^{N} \overline{X_{\imath}}}{k} \\
& \overline{\bar{Y}}=\frac{\sum_{i=1}^{N} \overline{Y_{l}}}{k}
\end{aligned}
$$

Dimana:

$\mathrm{K}$ = Banyaknya atribut atau fakta yang dapat mempengaruhi kepuasan kontraktor terhadap kinerja klien

5. Selanjutnya tingkat unsur-unsur tersebut akan dijabarkan dan dibagi menjadi empat bagian kedalam diagram kartesius seperti pada gambar.

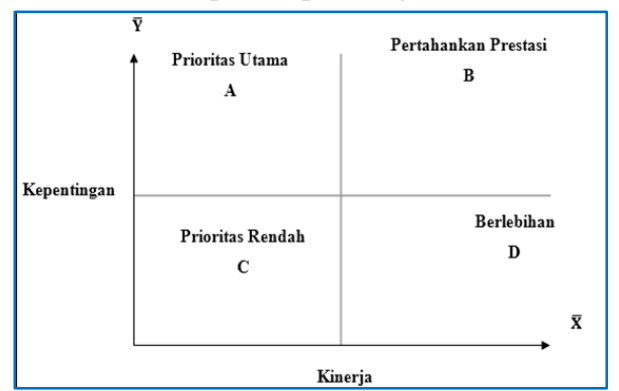

Gambar 1. Diagram Kartesius

Importance Performance Analysis

(Sumber : Hasil Analisis, 2018)

Keterangan:

a. Kuadran A Menunjukkan bahwa variabel dalam kuadran ini dianggap sangat penting oleh kontraktor, tetapi tidak banyak dilaksanakan oleh klien.

b. Kuadran B Menunjukkan variabel dalam kuadaran ini penting terhadap kinerja klien dan berhasil dilaksanakan oleh klien.

c. Kuadran C Menunjukkan variabel dalam kuadaran ini dinilai kurang penting pengaruhnya terhadap kontraktor, dan dilaksanakan oleh klien secara biasa saja. d. Kuadran D Menunjukkan variabel dalam kuadran ini dinilai kurang penting sedangkan pelaksanaannya berlebihan.

\section{Metode Penelitian}

Data yang dikumpulkan melalui kuesioner dan observasi untuk data primer disebarkan kepada pemilik proyek, manajemen konstruksi, konsultan pengawas, tim teknis konsultan, dan perwakilan pemilik proyek yang lain setingkat manajerial dan teknis yang berkompeten. Studi literatur digunakan untuk data sekunder.

Analisis data untuk mengetahui tingkat kepuasan pelanggan dalam analisis data pada penelitian ini dilakukan dengan menggunakan metode Customer Satisfaction Index (CSI), analisis GAP, dan Important Performance Analysis (IPA).

\section{Diagram Alur Penelitian}

Bagan alur penelitian dengan tahapantahapan pekerjaan yang akan dilakukan pada penelitian ini diilustrasikan sebagai berikut : 




Gambar 2. Bagan Alur Penelitian

(Sumber : Hasil Analisis, 2018)

\section{Analisis dan Pembahasan}

Pada tahap pertama semua indikator di susun dari kajian yang telah peneliti kumpulkan untuk melakukan validasi kepada 5 orang ahli. Responden pada tahap ini terdiri dari ahli dengan latar belakang bidang praktisi profesional teknik sipil. Survey pendahuluan dan rancangan kuisioner ini dimaksudkan untuk menyurvey proyek pembangunan Bendungan KLM yang akan dijadikan objek penelitian, untuk mendapatkan verifikasi, klarifikasi dan validasi indikator - indikator yang digunakan dalam penelitian ini. Berikut adalah data ahli pada tahap ini.

Tabel 1. Data Ahli di Bidang Konstruksi

\begin{tabular}{|c|c|c|c|}
\hline Ahli & $\begin{array}{c}\text { Pendidi } \\
\text { kan }\end{array}$ & Jabatan & $\begin{array}{c}\text { Pengalaman } \\
\text { (Thn) }\end{array}$ \\
\hline 1 & S2 & Dosen Tetap & 30 \\
\hline 2 & S1 & Road Engineer & 25 \\
\hline 3 & S1 & $\begin{array}{c}\text { Construction } \\
\text { Engineer }\end{array}$ & 25 \\
\hline
\end{tabular}

\begin{tabular}{|c|c|c|c|}
\hline Ahli & $\begin{array}{c}\text { Pendidi } \\
\text { kan }\end{array}$ & Jabatan & $\begin{array}{c}\text { Pengalaman } \\
\text { (Thn) }\end{array}$ \\
\hline 4 & S2 & $\begin{array}{c}\text { Structure } \\
\text { Engineer }\end{array}$ & $>30$ \\
\hline 5 & S1 & $\begin{array}{c}\text { Geologist \& } \\
\text { Grouting } \\
\text { Engineer }\end{array}$ & 25 \\
\hline
\end{tabular}

Sumber : Hasil Analisis, 2018

Para ahli tersebut memberikan tanggapan, perbaikan dan masukan terhadap 36 indikator kepuasan pengguna jasa kontraktor yang diajukan. Selanjutnya tanggapan dan perbaikan dari ke-5 ahli dibandingkan, apabila ada suatu indikator yang lebih dominan tidak disetujui maka indikator tersebut akan dihilangkan dan tidak digunakan pada pengumpulan data tahap kedua.

Setelah melakukan survey pendahuluan dan rancangan kuesioner didapat indikator penelitian, kemudian dilanjutkan dengan pengumpulan data tahap kedua. Pada tahap kedua pengumpulan data dilakukan dengan menyebarkan kuesioner kepada responden. Dari 45 kuesioner yang disebar, 40 kuisioner dikembalikan.

\section{Uji Validitas}

Pada pengujian validitas tiap variabel menggunakan metode korelasi bivariate pearson.

Tabel 2. Hasil Perhitungan Pengujian Validitas output SPSS v.24 Trial

\begin{tabular}{|c|c|c|c|c|}
\hline No & $\begin{array}{c}\text { Hasil } \\
\text { Uji - } \\
\text { Kepua } \\
\text { san }\end{array}$ & $\begin{array}{c}\text { Hasil } \\
\text { Uji } \\
\text { Kepe } \\
\text { nting } \\
\text { an }\end{array}$ & $\begin{array}{c}\mathrm{R} \\
\text { tabel } \\
5 \% \\
(\mathrm{~N}=40 \\
)\end{array}$ & $\begin{array}{c}\text { Keterang } \\
\text { an }\end{array}$ \\
\hline 1 & 0.882 & 0.869 & 0.312 & Valid \\
\hline 2 & 0.793 & 0.884 & 0.312 & Valid \\
\hline 3 & 0.818 & 0.821 & 0.312 & Valid \\
\hline 4 & 0.803 & 0.800 & 0.312 & Valid \\
\hline 5 & 0.733 & 0.749 & 0.312 & Valid \\
\hline 6 & 0.842 & 0.699 & 0.312 & Valid \\
\hline 7 & 0.913 & 0.878 & 0.312 & Valid \\
\hline 8 & 0.908 & 0.941 & 0.312 & Valid \\
\hline
\end{tabular}




\begin{tabular}{|c|c|c|c|c|}
\hline No & $\begin{array}{l}\text { Hasil } \\
\text { Uji - } \\
\text { Kepua } \\
\text { san }\end{array}$ & $\begin{array}{c}\text { Hasil } \\
\text { Uji - } \\
\text { Kepe } \\
\text { nting } \\
\text { an }\end{array}$ & $\begin{array}{c}\mathrm{R} \\
\text { tabel } \\
5 \% \\
(\mathrm{~N}=40 \\
)\end{array}$ & $\begin{array}{c}\text { Keterang } \\
\text { an }\end{array}$ \\
\hline 9 & 0.821 & 0.894 & 0.312 & Valid \\
\hline 10 & 0.896 & 0.905 & 0.312 & Valid \\
\hline 11 & 0.781 & 0.849 & 0.312 & Valid \\
\hline 12 & 0.821 & 0.910 & 0.312 & Valid \\
\hline 13 & 0.905 & 0.943 & 0.312 & Valid \\
\hline 14 & 0.878 & 0.944 & 0.312 & Valid \\
\hline 15 & 0.943 & 0.888 & 0.312 & Valid \\
\hline 16 & 0.915 & 0.852 & 0.312 & Valid \\
\hline 17 & 0.841 & 0.895 & 0.312 & Valid \\
\hline 18 & 0.874 & 0.900 & 0.312 & Valid \\
\hline 19 & 0.858 & 0.875 & 0.312 & Valid \\
\hline 20 & 0.843 & 0.906 & 0.312 & Valid \\
\hline 21 & 0.540 & 0.791 & 0.312 & Valid \\
\hline 22 & 0.531 & 0.790 & 0.312 & Valid \\
\hline 23 & 0.784 & 0.931 & 0.312 & Valid \\
\hline 24 & 0.780 & 0.908 & 0.312 & Valid \\
\hline 25 & 0.876 & 0.878 & 0.312 & Valid \\
\hline 26 & 0.797 & 0.806 & 0.312 & Valid \\
\hline 27 & 0.880 & 0.937 & 0.312 & Valid \\
\hline 28 & 0.804 & 0.866 & 0.312 & Valid \\
\hline 29 & 0.925 & 0.915 & 0.312 & Valid \\
\hline 30 & 0.830 & 0.817 & 0.312 & Valid \\
\hline 31 & 0.839 & 0.847 & 0.312 & Valid \\
\hline 32 & 0.710 & 0.757 & 0.312 & Valid \\
\hline 33 & 0.882 & 0.936 & 0.312 & Valid \\
\hline 34 & 0.869 & 0.934 & 0.312 & Valid \\
\hline 35 & 0.899 & 0.870 & 0.312 & Valid \\
\hline 36 & 0.812 & 0.815 & 0.312 & Valid \\
\hline
\end{tabular}

Sumber : Hasil Analisis, 2018

Berdasarkan pengujian, pada tabel diatas tidak terdapat variabel yang tidak valid, hal tersebut dikarenakan nilai $r$ hitung $>r$ tabel dengan nilai $r$ tabel $0,312(n=40)$ dengan level of significance 5\%.

\section{Uji Reabilitas}

Uji Reliabilitas dengan Uji Cronbach's Alpha, merupakan ukuran keandalan yang memiliki niali berkisar dari nol sampai satu (Hair et al.; 2010:92).

\section{Tabel 3. Hasil Perhitungan Pengujian Realibilitas Kepuasan Output SPSS v.24} Trial

\begin{tabular}{|c|c|c|c|}
\hline $\begin{array}{c}\text { Total } \\
\text { Variabel }\end{array}$ & $\begin{array}{c}\text { Croncbach's } \\
\text { Alpha } \\
\text { Hitung }\end{array}$ & $\begin{array}{c}\text { Croncbach's } \\
\text { Alpha Tabel }\end{array}$ & Keterangan \\
\hline 36 & 0.986 & 0.312 & Reliabel \\
\hline
\end{tabular}

\section{Tabel 4. Hasil Perhitungan Pengujian} Realibilitas Kepentingan Output SPSS v.24 Trial

\begin{tabular}{|c|c|c|c|}
\hline $\begin{array}{c}\text { Total } \\
\text { Variabel }\end{array}$ & $\begin{array}{c}\text { Croncbach's } \\
\text { Alpha } \\
\text { Hitung }\end{array}$ & $\begin{array}{c}\text { Croncbach's } \\
\text { Alpha Tabel }\end{array}$ & Keterangan \\
\hline 36 & 0.99 & 0.312 & Reliabel \\
\hline
\end{tabular}

Sumber : Hasil Analisis, 2018

\section{Customer Satisfaction Index (CSI)}

Berikut ini perhitungan CSI yang didapatkan dari perbandingan antara tingkat kepentingan dan tingkat kepuasan kinerja manajemen proyek kontraktor besar bendungan KLM.

Tabel 6. Perhitungan Customer Satisfaction Index (CSI)

\begin{tabular}{|c|c|c|c|c|} 
Var & $\begin{array}{c}\text { Mean } \\
\text { Skor } \\
\text { Kepentin } \\
\text { gan }\end{array}$ & $\begin{array}{c}\text { Weightin } \\
\text { g Factor }\end{array}$ & $\begin{array}{c}\text { Mean } \\
\text { Skor } \\
\text { Kepua } \\
\text { san }\end{array}$ & $\begin{array}{c}\text { Weighti } \\
\text { ng } \\
\text { Score }\end{array}$ \\
\hline (a) & (b) & $\begin{array}{c}\text { c } \\
\text { (b/btotal } \\
\text { ) } 100 \%\end{array}$ & (d) & e = c*d \\
\hline P1 & 5.2 & 2.65 & 4.1 & 0.11 \\
\hline P2 & 5.2 & 2.68 & 4.2 & 0.11 \\
\hline P3 & 5.5 & 2.83 & 4.0 & 0.11 \\
\hline P4 & 5.4 & 2.77 & 4.2 & 0.12 \\
\hline P5 & 5.0 & 2.58 & 4.1 & 0.11 \\
\hline P6 & 5.1 & 2.59 & 4.2 & 0.11 \\
\hline S1 & 5.6 & 2.85 & 3.8 & 0.11 \\
\hline S2 & 6.0 & 3.06 & 3.9 & 0.12 \\
\hline S3 & 5.3 & 2.71 & 4.2 & 0.11 \\
\hline S4 & 5.1 & 2.63 & 4.2 & 0.11 \\
\hline S5 & 5.2 & 2.67 & 4.2 & 0.11 \\
\hline S6 & 5.9 & 3.03 & 4.7 & 0.14 \\
\hline S7 & 5.2 & 2.67 & 3.9 & 0.10 \\
\hline S8 & 6.0 & 3.06 & 4.1 & 0.13 \\
\hline S9 & 5.6 & 2.85 & 4.2 & 0.12 \\
\hline S10 & 5.6 & 2.85 & 4.1 & 0.12 \\
\hline S11 & 5.1 & 2.62 & 4.2 & 0.11 \\
\hline & & & & \\
\hline
\end{tabular}




\begin{tabular}{|c|c|c|c|c|}
\hline Var & $\begin{array}{c}\text { Mean } \\
\text { Skor } \\
\text { Kepentin } \\
\text { gan }\end{array}$ & $\begin{array}{l}\text { Weightin } \\
\text { g Factor }\end{array}$ & $\begin{array}{c}\text { Mean } \\
\text { Skor } \\
\text { Kepua } \\
\text { san }\end{array}$ & $\begin{array}{c}\text { Weighti } \\
\text { ng } \\
\text { Score }\end{array}$ \\
\hline S12 & 5.2 & 2.65 & 4.1 & 0.11 \\
\hline S13 & 5.4 & 2.78 & 4.1 & 0.11 \\
\hline S14 & 5.1 & 2.63 & 4.1 & 0.11 \\
\hline S15 & 5.2 & 2.67 & 4.2 & 0.11 \\
\hline S16 & 5.7 & 2.94 & 4.3 & 0.12 \\
\hline S17 & 6.0 & 3.06 & 4.2 & 0.13 \\
\hline S18 & 5.1 & 2.60 & 3.9 & 0.10 \\
\hline S19 & 5.8 & 2.97 & 4.2 & 0.12 \\
\hline S20 & 5.4 & 2.77 & 4.3 & 0.12 \\
\hline S21 & 6.0 & 3.08 & 4.3 & 0.13 \\
\hline S22 & 5.2 & 2.67 & 4.1 & 0.11 \\
\hline S23 & 5.7 & 2.92 & 3.7 & 0.11 \\
\hline S24 & 5.0 & 2.54 & 4.0 & 0.10 \\
\hline S25 & 5.6 & 2.85 & 4.1 & 0.12 \\
\hline S26 & 5.6 & 2.86 & 4.2 & 0.12 \\
\hline S27 & 5.1 & 2.63 & 4.0 & 0.10 \\
\hline S28 & 6.0 & 3.06 & 4.1 & 0.12 \\
\hline S29 & 5.1 & 2.62 & 4.4 & 0.11 \\
\hline S30 & 5.1 & 2.59 & 4.3 & 0.11 \\
\hline Total & 195 & $100 \%$ & 149.4 & \\
\hline \multicolumn{4}{|c|}{ Weighted Total = इweighting Score } & 4.12 \\
\hline \multicolumn{4}{|c|}{$\begin{array}{c}\text { Satisfaction Index }=(\text { Weighted } \\
\text { Total } / \text { Scale }(6))^{* 100 \%}\end{array}$} & $\begin{array}{c}68.64 \\
\%\end{array}$ \\
\hline
\end{tabular}

Sumber : Hasil Analisis, 2018

\section{Analisis GAP}

Perhitungan evaluasi kepuasan pelanggan dilakukan dengan menghitung selisih (gap) antara penilaian skor tingkat kepuasan dengan penilaian skor tingkat kepentingan untuk seluruh variabel-variabel evaluasi kinerja manajemen proyek.

Tabel 7. Analisa GAP Variabel Kinerja Manajemen Proyek

\begin{tabular}{|c|c|c|c|c|}
\hline Var & $\begin{array}{c}\text { Skor } \\
\text { Kepu } \\
\text { asan }\end{array}$ & $\begin{array}{c}\text { Skor } \\
\text { Kepen } \\
\text { tingan }\end{array}$ & $\begin{array}{c}\text { Skor } \\
\text { GAP }\end{array}$ & Penilaian \\
\hline a & c & d & $\begin{array}{c}\text { e }=\mathrm{d}- \\
\text { c }\end{array}$ & e \\
\hline P1 & 164 & 207 & 43 & Puas \\
\hline P2 & 168 & 209 & 41 & Puas \\
\hline P3 & 161 & 217 & 56 & $\begin{array}{c}\text { Cukup } \\
\text { Puas }\end{array}$ \\
\hline P4 & 169 & 216 & 47 & Puas \\
\hline P5 & 165 & 201 & 36 & $\begin{array}{c}\text { Sangat } \\
\text { Puas }\end{array}$ \\
\hline
\end{tabular}

\begin{tabular}{|c|c|c|c|c|}
\hline Var & $\begin{array}{c}\text { Skor } \\
\text { Kepu } \\
\text { asan }\end{array}$ & $\begin{array}{l}\text { Skor } \\
\text { Kepen } \\
\text { tingan }\end{array}$ & $\begin{array}{l}\text { Skor } \\
\text { GAP }\end{array}$ & Penilaian \\
\hline P6 & 169 & 202 & 33 & $\begin{array}{l}\text { Sangat } \\
\text { Puas }\end{array}$ \\
\hline S1 & 151 & 222 & 71 & $\begin{array}{l}\text { Tidak } \\
\text { Puas }\end{array}$ \\
\hline S2 & 155 & 239 & 84 & $\begin{array}{c}\text { Sangat } \\
\text { Tidak } \\
\text { Puas }\end{array}$ \\
\hline S3 & 166 & 211 & 45 & Puas \\
\hline S4 & 166 & 205 & 39 & $\begin{array}{l}\text { Sangat } \\
\text { Puas }\end{array}$ \\
\hline S5 & 168 & 208 & 40 & $\begin{array}{l}\text { Sangat } \\
\text { Puas }\end{array}$ \\
\hline S6 & 187 & 236 & 49 & Puas \\
\hline S7 & 154 & 208 & 54 & $\begin{array}{l}\text { Cukup } \\
\text { Puas }\end{array}$ \\
\hline S8 & 164 & 239 & 75 & $\begin{array}{c}\text { Sangat } \\
\text { Tidak } \\
\text { Puas }\end{array}$ \\
\hline S9 & 166 & 222 & 56 & $\begin{array}{l}\text { Cukup } \\
\text { Puas }\end{array}$ \\
\hline S10 & 165 & 222 & 57 & $\begin{array}{c}\text { Cukup } \\
\text { Puas }\end{array}$ \\
\hline S11 & 167 & 204 & 37 & $\begin{array}{c}\text { Sangat } \\
\text { Puas }\end{array}$ \\
\hline S12 & 165 & 207 & 42 & Puas \\
\hline S13 & 162 & 217 & 55 & $\begin{array}{l}\text { Cukup } \\
\text { Puas }\end{array}$ \\
\hline S14 & 162 & 205 & 43 & Puas \\
\hline S15 & 168 & 208 & 40 & $\begin{array}{c}\text { Sangat } \\
\text { Puas }\end{array}$ \\
\hline S16 & 170 & 229 & 59 & $\begin{array}{c}\text { Cukup } \\
\text { Puas }\end{array}$ \\
\hline S17 & 166 & 239 & 73 & $\begin{array}{l}\text { Tidak } \\
\text { Puas }\end{array}$ \\
\hline S18 & 155 & 203 & 48 & Puas \\
\hline S19 & 166 & 232 & 66 & $\begin{array}{l}\text { Tidak } \\
\text { Puas }\end{array}$ \\
\hline $\mathrm{S} 20$ & 172 & 216 & 44 & Puas \\
\hline $\mathrm{S} 21$ & 171 & 240 & 69 & $\begin{array}{l}\text { Tidak } \\
\text { Puas }\end{array}$ \\
\hline S22 & 164 & 208 & 44 & Puas \\
\hline S23 & 149 & 228 & 79 & $\begin{array}{c}\text { Sangat } \\
\text { Tidak } \\
\text { Puas }\end{array}$ \\
\hline $\mathrm{S} 24$ & 158 & 198 & 40 & $\begin{array}{c}\text { Sangat } \\
\text { Puas }\end{array}$ \\
\hline $\mathrm{S} 25$ & 165 & 222 & 57 & $\begin{array}{l}\text { Cukup } \\
\text { Puas }\end{array}$ \\
\hline S26 & 169 & 223 & 54 & $\begin{array}{c}\text { Cukup } \\
\text { Puas }\end{array}$ \\
\hline S27 & 159 & 205 & 46 & Puas \\
\hline
\end{tabular}




\begin{tabular}{|c|c|c|c|c|}
\hline Var & $\begin{array}{c}\text { Skor } \\
\text { Kepu } \\
\text { asan }\end{array}$ & $\begin{array}{c}\text { Skor } \\
\text { Kepen } \\
\text { tingan }\end{array}$ & $\begin{array}{c}\text { Skor } \\
\text { GAP }\end{array}$ & Penilaian \\
\hline S28 & 162 & 239 & 77 & $\begin{array}{c}\text { Sangat } \\
\text { Tidak } \\
\text { Puas }\end{array}$ \\
\hline S29 & 174 & 204 & 30 & $\begin{array}{c}\text { Sangat } \\
\text { Puas }\end{array}$ \\
\hline S30 & 173 & 202 & 29 & $\begin{array}{c}\text { Sangat } \\
\text { Puas }\end{array}$ \\
\hline
\end{tabular}

Sumber : Hasil Analisis, 2018

\section{Important Performance Analysis (IPA)}

Analisis diagram kartesius (important performance analysis) digunakan untuk mengetahui pengklasifikasian kinerja manajemen proyek kontraktor yang terbagi ke dalam empat kuadran, yaitu kuadran a, kuadran b, kuadran c, dan kuadran d. Di mana sumbu mendatar (x) dari diagram kartesius merupakan tingkat kepuasan pelanggan dan sumbu tegak (y) merupakan tingkat kepentingan/ harapan dari pelanggan terhadap kinerja manajemen proyek kontraktor besar.

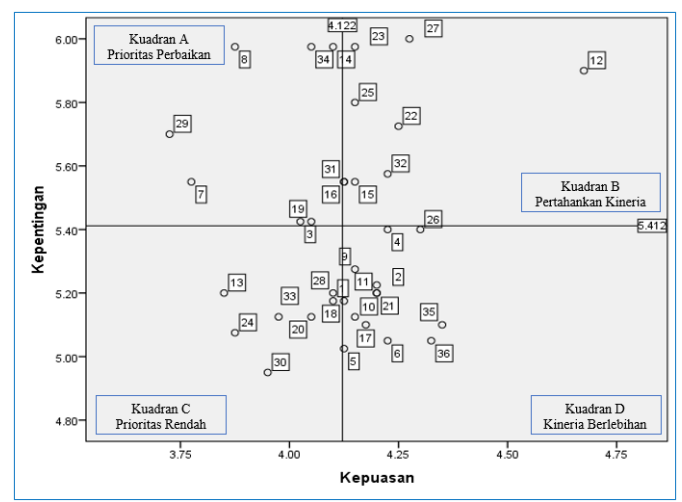

Gambar 3. Diagram Kartesius Kinerja Manajemen Proyek Kontraktor Besar (Sumber : Hasil Analisis, 2018)

Dari diagram kartesius di atas, masingmasing variabel pengukuran kinerja manajemen proyek akan diklasifikasikan ke dalam empat kuadran, yaitu kuadran a, kuadran b, kuadran c, dan kuadran d. Berikut akan dijelaskan mengenai pengertian masing-masing kuadran beserta variabel-variabel kinerja manajemen proyek yang termasuk ke dalam kuadran tersebut sebagai berikut :

1. Diagram Kartesius Kuadran A (Prioritas Perbaikan)

Kuadran A menunjukkan daerah yang memiliki tingkat kepuasan yang rendah sedangkan tingkat kepentingan/ harapan yang tinggi. Oleh karena itu variabelvariabel kinerja manajemen proyek pada kuadran ini perlu untuk diprioritaskan/ ditingkatkan kinerjanya, karena keberadaan variabel-variabel ini dinilai sangat penting oleh pengguna jasa, sedangkan dalam pelaksanaannya masih belum memuaskan.

\section{Tabel 8. Variabel-variabel kinerja manajemen proyek pada Kuadran $A$}

\begin{tabular}{|c|c|c|c|c|}
\hline No & Var. & $\begin{array}{c}\text { Variabel } \\
\text { Pengukuran }\end{array}$ & $\begin{array}{l}\text { Kepu } \\
\text { asan }\end{array}$ & $\begin{array}{l}\text { Kepen } \\
\text { tingan }\end{array}$ \\
\hline \multicolumn{5}{|c|}{ Product } \\
\hline 1 & P3 & $\begin{array}{l}\text { Lingkup pekerjaan } \\
\text { sesuai dokumen } \\
\text { kontrak }\end{array}$ & 4.03 & 5.40 \\
\hline \multicolumn{5}{|c|}{ Service } \\
\hline 1 & S1 & $\begin{array}{l}\text { Rencana pekerjaan } \\
\text { (penjadwalan) } \\
\text { yang realistis }\end{array}$ & 3.78 & 5.55 \\
\hline 2 & $\mathrm{~S} 2$ & $\begin{array}{l}\text { Ketepatan waktu } \\
\text { penyelesaian } \\
\text { proyek }\end{array}$ & 3.88 & 5.98 \\
\hline 3 & S8 & $\begin{array}{l}\text { Kecepatan } \\
\text { menangani } \\
\text { masalah (biaya, } \\
\text { mutu, waktu, } \\
\text { konflik, dsb) yang } \\
\text { terjadi di lapangan }\end{array}$ & 4.10 & 5.98 \\
\hline 4 & S13 & $\begin{array}{l}\text { Menginformasikan } \\
\text { risiko yang } \\
\text { mungkin dapat } \\
\text { terjadi selama } \\
\text { konstruksi }\end{array}$ & 4.05 & 5.43 \\
\hline 5 & S23 & $\begin{array}{l}\text { Peralatan yang } \\
\text { digunakan canggih } \\
\text { dan modern }\end{array}$ & 3.73 & 5.70 \\
\hline 6 & S28 & $\begin{array}{l}\text { Jaminan kualitas } \\
\text { dari perusahaan }\end{array}$ & 4.05 & 5.98 \\
\hline
\end{tabular}

Sumber : Hasil Analisis, 2018 


\section{Diagram Kartesius Kuadran B} (Pertahankan Kinerja)

Kuadran B menunjukkan daerah yang memiliki tingkat kepuasan dan kepentingan yang tinggi, dengan kata lain pelanggan sudah merasa puas. Oleh karena itu variabelvariabel kinerja manajemen proyek pada kuadran ini perlu untuk dipertahankan kinerjanya, karena pada umumnya tingkat pelaksanaannya telah sesuai dengan kepentingan/ harapan pelanggan.

\begin{tabular}{|c|c|c|c|c|}
\hline No & Var & $\begin{array}{c}\text { Variabel } \\
\text { Pengukuran }\end{array}$ & $\begin{array}{l}\text { Kepua } \\
\text { san }\end{array}$ & $\begin{array}{c}\text { Kepenti } \\
\text { ngan }\end{array}$ \\
\hline \multicolumn{5}{|c|}{ Service } \\
\hline 1 & S6 & $\begin{array}{l}\text { Kesesuaian } \\
\text { laporan proyek } \\
\text { dengan kondisi } \\
\text { aktual di } \\
\text { lapangan }\end{array}$ & 4.68 & 5.90 \\
\hline 2 & S9 & $\begin{array}{l}\text { Kecepatan dalam } \\
\text { merespon } \\
\text { permintaan } \\
\text { pemilik proyek }\end{array}$ & 4.15 & 5.55 \\
\hline 3 & $\mathrm{~S} 10$ & $\begin{array}{l}\text { Keandalan } \\
\text { menangani } \\
\text { masalah (biaya, } \\
\text { mutu, waktu, } \\
\text { konflik, dsb) } \\
\text { yang terjadi di } \\
\text { lapangan }\end{array}$ & 4.13 & 5.55 \\
\hline 4 & S16 & $\begin{array}{l}\text { Sistem } \\
\text { keselamatan dan } \\
\text { kesehatan kerja } \\
\text { (K3) selama } \\
\text { konstruksi }\end{array}$ & 4.25 & 5.73 \\
\hline 5 & S17 & $\begin{array}{l}\text { Minimnya } \\
\text { pengerjaan ulang } \\
\text { (repair/rework) } \\
\text { selama } \\
\text { pelaksanaan } \\
\text { proyek }\end{array}$ & 4.15 & 5.98 \\
\hline 6 & S19 & $\begin{array}{l}\text { Sumber daya } \\
\text { manusia yang } \\
\text { berkompeten/ } \\
\text { berkualitas }\end{array}$ & 4.15 & 5.80 \\
\hline 7 & S21 & $\begin{array}{l}\text { Ketepatan } \\
\text { metode kerja }\end{array}$ & 4.28 & 6.00 \\
\hline
\end{tabular}

\begin{tabular}{|c|c|c|c|c|}
\hline No & Var & $\begin{array}{c}\text { Variabel } \\
\text { Pengukuran }\end{array}$ & $\begin{array}{c}\text { Kepua } \\
\text { san }\end{array}$ & $\begin{array}{c}\text { Kepenti } \\
\text { ngan }\end{array}$ \\
\hline & & $\begin{array}{l}\text { konstruksi yang } \\
\text { digunakan }\end{array}$ & & \\
\hline 8 & S25 & $\begin{array}{l}\text { Pengawasan dan } \\
\text { pengendalian } \\
\text { proyek } \\
\text { dilakukan secara } \\
\text { teratur/ } \\
\text { terjadwal }\end{array}$ & 4.13 & 5.55 \\
\hline 9 & S26 & $\begin{array}{l}\text { Adanya sistem } \\
\text { manajemen } \\
\text { mutu selama } \\
\text { masa konstruksi }\end{array}$ & 4.23 & 5.58 \\
\hline
\end{tabular}

Sumber : Hasil Analisis, 2018

3. Diagram Kartesius Kuadran C (Prioritas Rendah)

Kuadaran C menunjukkan daerah yang memiliki tingkat kepuasan rendah sedangkan tingkat kepentingannya juga rendah. Dengan kata lain pelanggan tidak terlalu mengharapkan perbaikan kinerja untuk variabel ini. Untuk itu variabelvariabel kinerja manajemen proyek pada kuadran ini tidak perlu diprioritaskan/ ditingkatkan dan termasuk prioritas rendah karena dianggap masih kurang penting bagi pelanggan, dan dalam pelaksanaannya biasa/cukup saja.

\section{Tabel 10. Variabel-variabel kinerja manajemen proyek pada Kuadran $\mathrm{C}$}

\begin{tabular}{|c|c|l|c|c|}
\hline No & Var. & \multicolumn{1}{|c|}{$\begin{array}{c}\text { Variabel } \\
\text { Pengukuran }\end{array}$} & $\begin{array}{c}\text { Kepuas } \\
\text { an }\end{array}$ & $\begin{array}{c}\text { Kepen } \\
\text { tingan }\end{array}$ \\
\hline 1 & P1 & $\begin{array}{l}\text { Pemenuhan } \\
\text { terhadap fungsi } \\
\text { bangunan }\end{array}$ & 4.10 & 5.18 \\
\hline Product & S7 & $\begin{array}{l}\text { Ketepatan dalam } \\
\text { memilih supplier } \\
\text { dan } \\
\text { Service }\end{array}$ & 3.85 & 5.20 \\
\hline 2 & S14 & $\begin{array}{l}\text { Komunikasi yang } \\
\text { terintegrasi } \\
\text { antara }\end{array}$ & 5.13 \\
\hline
\end{tabular}




\begin{tabular}{|c|c|c|c|c|}
\hline No & Var. & $\begin{array}{c}\text { Variabel } \\
\text { Pengukuran }\end{array}$ & $\begin{array}{l}\text { Kepuas } \\
\text { an }\end{array}$ & $\begin{array}{l}\text { Kepen } \\
\text { tingan }\end{array}$ \\
\hline & & $\begin{array}{l}\text { kontraktor, } \\
\text { subkontraktor } \\
\text { dan supplier. }\end{array}$ & & \\
\hline 3 & S18 & $\begin{array}{l}\text { Struktur } \\
\text { organisasi } \\
\text { pengelola proyek } \\
\text { yang lengkap }\end{array}$ & 3.88 & 5.08 \\
\hline 4 & S22 & $\begin{array}{l}\text { Kebersihan di } \\
\text { lapangan selama } \\
\text { masa konstruksi }\end{array}$ & 4.10 & 5.20 \\
\hline 5 & S24 & $\begin{array}{l}\text { Karyawan } \\
\text { berpenampilan } \\
\text { rapi dan } \\
\text { profesional }\end{array}$ & 3.95 & 4.95 \\
\hline 6 & $\mathrm{~S} 27$ & $\begin{array}{l}\text { Sistem } \\
\text { manajemen } \\
\text { kualitas ditinjau } \\
\text { oleh sebuah } \\
\text { badan / instansi } \\
\text { independen. }\end{array}$ & 3.98 & 5.13 \\
\hline
\end{tabular}

Sumber : Hasil Analisis, 2018

\section{Diagram Kartesius Kuadran D (Kinerja Berlebihan)}

Kuadran D menunjukkan daerah yang memiliki tingkat kepuasan yang tinggi sedangkan tingkat kepentingannya rendah. Dengan kata lain pelanggan puas terhadap kinerjanya akan tetapi tidak menganggap begitu penting. Untuk itu variabel-variabel kinerja manajemen proyek pada kuadran ini dapat dikurangi kinerjanya, karena pelanggan menganggap adanya variabel tersebut tidak terlalu penting sedangkan kualitas pelaksanaannya sangat baik.

\section{Tabel 11. Variabel-variabel kinerja manajemen proyek pada Kuadran D}

\begin{tabular}{|c|c|c|c|c|}
\hline No & Var. & $\begin{array}{c}\text { Variabel } \\
\text { Pengukuran }\end{array}$ & Kepuasan & $\begin{array}{c}\text { Kepen } \\
\text { tingan }\end{array}$ \\
\hline 1 & P2 & $\begin{array}{l}\text { Fitur-fitur yang } \\
\text { melengkapi } \\
\text { produk } \\
\text { konstruksi }\end{array}$ & 4.20 & 5.23 \\
\hline \multicolumn{2}{|c|}{} & & \\
\hline
\end{tabular}

\begin{tabular}{|c|c|c|c|c|}
\hline No & Var. & $\begin{array}{c}\text { Variabel } \\
\text { Pengukuran }\end{array}$ & Kepuasan & $\begin{array}{l}\text { Kepen } \\
\text { tingan }\end{array}$ \\
\hline & & $\begin{array}{l}\text { berfungsi dengan } \\
\text { baik }\end{array}$ & & \\
\hline 2 & P4 & $\begin{array}{l}\text { Kualitas } \\
\text { bangunan sesuai } \\
\text { spesifikasi teknis }\end{array}$ & 4.23 & 5.40 \\
\hline 3 & P5 & $\begin{array}{l}\text { Kontraktor } \\
\text { cepat, baik, dan } \\
\text { berkompeten } \\
\text { dalam } \\
\text { pemeliharaan } \\
\text { produk } \\
\text { konstruksi }\end{array}$ & 4.13 & 5.03 \\
\hline 4 & P6 & $\begin{array}{l}\text { Kerapian } \\
\text { (Estetika) hasil } \\
\text { akhir bangunan }\end{array}$ & 4.23 & 5.05 \\
\hline \multicolumn{5}{|c|}{ Service } \\
\hline 1 & S3 & $\begin{array}{l}\text { Rutin dan tertib } \\
\text { dalam } \\
\text { administrasi }\end{array}$ & 4.15 & 5.28 \\
\hline 2 & S4 & $\begin{array}{l}\text { Kemudahan } \\
\text { pelayanan yang } \\
\text { diberikan }\end{array}$ & 4.15 & 5.13 \\
\hline 3 & S5 & $\begin{array}{l}\text { Shop drawing } \\
\text { diajukan } \\
\text { sebelum } \\
\text { pelaksanaan } \\
\text { konstruksi }\end{array}$ & 4.20 & 5.20 \\
\hline 4 & S11 & $\begin{array}{l}\text { Kemampuan } \\
\text { manajer proyek } \\
\text { dalam } \\
\text { berkomunikasi } \\
\text { baik secara } \\
\text { verbal maupun } \\
\text { tulisan }\end{array}$ & 4.18 & 5.10 \\
\hline 5 & S12 & $\begin{array}{l}\text { Menginformasik } \\
\text { an tentang } \\
\text { kepastian waktu } \\
\text { penyampaian } \\
\text { jasa / layanan }\end{array}$ & 4.13 & 5.18 \\
\hline 6 & S15 & $\begin{array}{l}\text { Penanganan } \\
\text { keamanan/ } \\
\text { sosialisasi di } \\
\text { lingkungan } \\
\text { proyek }\end{array}$ & 4.20 & 5.20 \\
\hline 7 & S20 & $\begin{array}{l}\text { Memperhatikan } \\
\text { masalah } \\
\text { lingkungan } \\
\text { dalam proses } \\
\text { konstruksi }\end{array}$ & 4.30 & 5.40 \\
\hline 8 & S29 & $\begin{array}{l}\text { Pemahaman } \\
\text { terhadap } \\
\text { keinginan dan }\end{array}$ & 4.35 & 5.10 \\
\hline
\end{tabular}




\begin{tabular}{|c|c|c|c|c|}
\hline No & Var. & $\begin{array}{c}\text { Variabel } \\
\text { Pengukuran }\end{array}$ & Kepuasan & $\begin{array}{l}\text { Kepen } \\
\text { tingan }\end{array}$ \\
\hline & & $\begin{array}{l}\text { kebutuhan } \\
\text { pemilik }\end{array}$ & & \\
\hline 9 & S30 & $\begin{array}{l}\text { Mengutamakan } \\
\text { kepentingan } \\
\text { pemilik }\end{array}$ & 4.33 & 5.05 \\
\hline
\end{tabular}

Sumber : Hasil Analisis, 2018

\section{Kesimpulan}

1. Identifikasi tingkat kepuasan pelanggan terhadap pelaksanaan manajemen proyek konstruksi dengan metode customer satisfaction index diperoleh nilai $68,64 \%$, nilai tersebut terletak pada rentang CSI 66,66\% - 83.33\% yang menunjukan bahwa pelanggan konstruksi telah merasa puas terhadap kinerja manajemen proyek kontraktor besar proyek pembangunan Bendungan KLM.

2. Berdasarkan analisa gap, nilai total skor gap tertinggi terdapat pada variabel ketepatan waktu penyelesaian proyek (S2) sebesar 84 yang berarti pelanggan merasa sangat tidak puas terhadap kinerja variabel tersebut, dan total skor gap terendah terdapat pada variabel mengutamakan kepentingan pemilik (S30) sebesar 29 yang berarti pelanggan merasa sangat puas terhadap kinerja variabel tersebut.

3. Berdasarkan metode important performance analysis diketahui variabel-variabel kinerja manajemen proyek yang pelaksanaannya telah memuaskan pelanggan dan perlu dipertahankan kinerjanya, yaitu variabel Kesesuaian laporan proyek dengan kondisi aktual di lapangan (S6), Kecepatan dalam merespon permintaan pemilik proyek (S9), Keandalan menangani masalah (biaya, mutu, waktu, konflik, dsb) yang terjadi di lapangan (S10), Sistem keselamatan dan kesehatan kerja (K3) selama konstruksi (S16), Minimnya pengerjaan ulang (repair/rework) selama pelaksanaan proyek (S17), Sumber daya manusia yang berkompeten/ berkualitas (S19), Ketepatan metode kerja konstruksi yang digunakan (S21), Pengawasan dan pengendalian proyek dilakukan secara teratur/ terjadwal (S25), Adanya sistem manajemen mutu selama masa konstruksi (S26). Dari kesembilan variabel tersebut, variabel kesesuaian laporan proyek dengan kondisi aktual di lapangan (S6) berada di posisi tertinggi dengan nilai mean kepuasan 4,7 dan mean kepentingan 5,9.

\section{Daftar Pustaka}

Bilson, Simamora. (2005). "Analisis Multivariat Pemasaran". Jakarta : Gramedia Pustaka Utama.

Fitriana, Dewi. dkk. (2014). "Pengukuran Kepuasan Kontraktor Terhadap Kinerja Klien Pada Proyek Konstruksi Swasta". Jurnal Karya Teknik Sipil. Vol. 3, No. 1. 2014 : 283-295.

Garvin, D.A. (1988) "Managing Quality”. The Free Press, New York.

Ichsan, Muhammad, (2015). "Studi Kinerja Perusahaan Konstruksi Dalam Lingkup Dinas Pekerjaan Umum Kota Makassar". Universitas Hasanuddin, Makassar.

Idrus, Arazi Bin. Sodangi, Mahmoud. (2010). "Framework for Evaluating Quality Performance of Contractors in Nigeria". Internatinal Journal of Civil \& Environmental Engineering. Vol. 10 No. 01. Februari 2010 : 31-36.

John A. Martilla dan John C. James. (1997). "Journal of Marketing". Vol. 41, No.1. Januari 1997.

Julia, Vica. (2015). “Tingkat Kepuasan Pengguna Jasa Pelayanan 
Kesyahbandaraan di Pelabuhan

Perikanan Samudera Nizam Zachman Jakarta". Institut Pertanian Bogor, Bogor.

Kementrian Pekerjaan Umum dan Perumahan Rakyat. 2018. "Buku Panduan Pembangunan Bendungan Serbaguna KLM". Jakarta: Kementrian Pekerjaan Umum dan Perumahan Rakyat.

Khasani, Riqi Radian. (2013). "Evaluasi

Kepuasan Pelanggan Terhadap Kinerja Manajemen Proyek Kontraktor Besar Bangunan Gedung”. Program Pascasarjana Universitas Diponegoro, Semarang.

Kirom, Bahrul. (2015). "Mengukur Kinerja Pelayanan dan Kepuasan Konsumen (Service Performance and Customer Satisfaction Measurement)". Cetakan Keempat (Edisi Revisi). Januari 2015. Pustaka Reka Cipta, Bandung.

Kotler, Philip. (2004). "Manajemen Pemasaran. Edisi Milenium". Jakarta : Indeks.

Kurniawan, Deddy. (2015). "Faktor-faktor Kritis Penentu Kepuasan Pelanggan Terhadap Proyek Kontraktor Bangunan Gedung Di Kota Bukittinggi". Program Pascasarjana Universitas Bung Hatta, Padang.

Lembaga Pengembangan Jasa konstruksi Nasional No. 3 Tahun 2017 Tentang Sertifikasi dan Rgistrasi Usaha Jasa Pelaksana Konstruksi. 2017. Jakarta.

Parasuraman, A., Zeithaml, V.A. and Berry, L.L. (1985) "A conceptual model of service quality and its implications for future research". Journal of Marketing. Vol. 49 No.4. Autumn 1985 : 41 - 50.

Project Management Institute Fifth Edition 2013 A Guide to the Project Management Body of Knowledge (PMBOK® Guide).
Pujiyono, Bambang. dkk. (2014). "Manajemen Proyek : Konsep Manajemen Proyek". ISBN 9789790115781. Universitas Terbuka, Jakarta. 1-42.

Rahman, Abdul. Alzubi, Yazan. (2015). "Exploring Key Contractor Factors Influencing Client Satisfaction Level in Dealing with Construction Project : an Empirical Study in Jordan". International Journal of Academic Research in Business and Social Science ISSN : 22226990. Vol. 5 No. 12. Desember 2015 : 109-126.

Sari, Kharisma Permata. Suraji, Akhmad. Fauzan. (2017). "Analisa Kepuasan Pelanggan Terhadap Penerapan Manajemen Proyek Konstruksi Pada Pekerjaan Rangka Atap Baja Ringan". Prosiding $4^{\text {th }}$ Andalas Civil Engineering (ACE) Conference. 9 November 2017. Universitas Andalas, Padang. 87-98.

Sumaga, Arfan Usman. (2013). "Analisis Kepuasan Pengguna Jasa Terhadap Penerapan Manajemen Rekayasa Konstruksi Profesional Ruko Di Kawasan Bussiness Park Kota Gorontalo". Jurnal Ilmiah Media Engineering ISSN : 2087-9334. Vol. 3 No. 1, Maret 2013 : 6-13.

Tjiptono, Fandy dan Gregorius Chandra. 2005. "Service, Quality \& Satisfaction". Andi. Yogyakarta.

Trisnawati, Luh Dewi. (2015). "Analisis Kinerja Proyek Terhadap Kepuasan Stakeholders". Program Pascasarjana Universitas Udayana, Denpasar.

Umbara, I Putu Yudha. (2016). “Kepuasan Pengguna Jasa Terhadap Konsultan Pengawas". Karya Tulis Ilmiah. Angka Kredit Pengembangan Profesi Jabatan Fungsional Pengadaan Barang/Jasa Pemerintah ULP Kabupaten Badung, Bali. 
Utami, Anin. (2004). “Kajian Risiko Proyek Rehabilitasi Bendungan Tailing (Studi Kasus Bendungan Limbah Tailing PT. KEM di Kalimantan Timur)". Universitas Teknologi Bandung, Bandung. 